\title{
Virulence and Stump Colonization Ability of Armillaria borealis on Norway Spruce Seedlings in Comparison to Sympatric Armillaria Species
}

\author{
Renate Heinzelmann, Simone Prospero, and Daniel Rigling, Swiss Federal Research Institute WSL, Zürcherstrasse 111, CH-8903
} Birmensdorf, Switzerland

\begin{abstract}
Although Armillaria borealis is one of the closest relatives of the aggressive root rot pathogen A. ostoyae, little is known about its ecology. In central and northern Europe, A. borealis often co-occurs with A. ostoyae or A. cepistipes, a weak pathogen, in conifer or mixed-forest stands. In this study, the virulence of $10 \mathrm{~A}$. borealis, nine A. ostoyae, and five A. cepistipes isolates toward 2- and 4-year-old potted Norway spruce (Picea abies) seedlings was assessed. In addition, the ability of all isolates to colonize fresh stumps cut from 6-year-old Norway spruce seedlings was tested. All inoculations were done by insertion of Armillaria-colonized hazelnut stem segments into the soil substrate. On the 2-year-old seedlings, A. borealis and

A. ostoyae showed, overall, a similar virulence 29 months after inoculation whereas, on the 4-year-old seedlings, A. ostoyae was more virulent. The third species in the experiment, A. cepistipes, caused almost no seedling mortality. Six months after cutting, the highest percentage of stumps was colonized by A. ostoyae (94.3\%), followed by A. borealis ( $85.2 \%)$, and A. cepistipes (78.4\%). Our inoculation experiments show that $A$. borealis has a clear pathogenic potential toward Norway spruce seedlings. However, compared with A. ostoyae, damage caused by A. borealis may decrease more rapidly with increasing tree age. Similar to other Armillaria species, A. borealis seems to be an efficient colonizer of fresh stumps.
\end{abstract}

Armillaria root disease has a major impact on woody plants in forests and timber and agronomic plantations worldwide, as it may considerably influence the structure and function of forest ecosystems and reduce timber quality and the productivity of trees (Baumgartner et al. 2011; Guillaumin et al. 2005). The causal agents of the disease are various species of the Agaricomycetes genus Armillaria. Among the species present in the northern hemisphere, A. ostoyae (Romagn.) Herink and A. mellea (Vahl: Fr.) P. Kumm. are recognized as aggressive primary pathogens that infect a very broad range of hosts (Guillaumin et al. 1993; Laflamme and Guillaumin 2005). Recently, their genomes were sequenced and released (http://1000.fungalgenomes.org) (Collins et al. 2013) and further sequencing projects are ongoing or completed for A. ostoyae, A. gallica Marxm. \& Romagn. and A. cepistipes Velen. (http://1000.fungalgenomes.org) (G. Sipos, personal communication, N. Klopfenstein, personal communication). To elucidate the genetic basis of virulence in Armillaria spp., critical comparisons are needed with other poorly investigated species, including A. borealis Marxm. \& Korhonen or A. gemina Bérubé \& Dessur., the two closest relatives of A. ostoyae (Brazee et al. 2011; Coetzee et al. 2011; Kim et al. 2006; Ross-Davis et al. 2012; Tsykun et al. 2013).

Both A. ostoyae and A. borealis occur in Europe, with the latter confined to northern and continental regions. The distribution ranges of the two species are largely overlapping in southern Scandinavia and central and eastern Europe (Marxmüller and Guillaumin 2005). In Scandinavia, A. borealis is a very common species (Keca and Solheim 2011; Korhonen 1978), whereas in central and eastern Europe, although being widespread, it is probably less abundant than the other annulated Armillaria species (Marxmüller and Guillaumin 2005; Marxmüller et al. 1990; Rigling et al. 1998). In western Europe, A. borealis is only known in northern France, The Netherlands, and Scotland (Marxmüller and Guillaumin 2005). Outside Europe, A. borealis is known in Siberia, China, and the mountainous regions of Iran (Asef et al. 2003; Pavlov 2015; Qin et al. 2007).

Corresponding author: R. Heinzelmann; E-mail: renate.heinzelmann@wsl.ch

*The $\boldsymbol{e}$-Xtra logo stands for "electronic extra" and indicates that three supplementary tables are published online.

Accepted for publication 19 October 2016.

() 2017 The American Phytopathological Society
Considering the high pathogenic potential and widespread occurrence of A. ostoyae, numerous studies have been conducted on this species (Legrand et al. 1996; Omdal et al. 1995; Prospero et al. 2004). In contrast, detailed knowledge about the ecology of $A$. borealis is largely lacking. Field observations indicate that $A$. borealis is less pathogenic than A. ostoyae and reports of A. borealis involved in primary attacks on living trees are rare (Gregory 1989; Gregory and Watling 1985). More often, A. borealis appears to act as a secondary pathogen, infecting and eventually killing trees already weakened by other abiotic or biotic factors (Bendel et al. 2006b; Gregory 1989; Gregory and Watling 1985; Keca and Solheim 2011; Korhonen 1978; Marxmüller et al. 1990; Pavlov 2015). In addition, A. borealis is known to cause heart rot in conifers (Gregory and Watling 1985; Keca and Solheim 2011; Korhonen 1978). Although A. borealis seems to have pathogenic potential, it is mostly reported as a saprotroph that colonizes stumps or decayed wood (Gregory and Watling 1985; Korhonen 1978; Marxmüller and Holdenrieder 2000; Marxmüller et al. 1990). While experimental data on the pathogenicity and virulence of $A$. borealis is very limited, findings suggest that $A$. borealis is similarly or less virulent than A. ostoyae toward conifer seedlings (Morrison 2004; Siepmann and Leibiger 1989). The host range of A. borealis includes coniferous as well as broadleaved trees (Gregory 1989; Korhonen 1978; Marxmüller et al. 1990).

Armillaria species infect the root system of their hosts either via rhizomorphs growing out of colonized wood (e.g., woody debris, stumps, dead roots) or through direct mycelial transfer when healthy roots come in contact with infected roots (Rishbeth 1985). Artificial inoculations are mainly conducted by burying a wood piece colonized by Armillaria species in the rooting zone of potted seedlings (Morrison 2004; Omdal et al. 1995; Prospero et al. 2004). From the wood piece, which acts as an inoculum source, rhizomorphs may develop and eventually infect the seedlings. Such inoculation experiments have proven to provide valuable information about the infection biology and pathogenicity of Armillaria species and the host resistance to Armillaria (Gregory et al. 1991; Morrison 2004; Omdal et al. 1995; Prospero et al. 2004). Potted seedlings have also been used to test the ability of Armillaria species to colonize fresh stumps via the roots, by cutting the tops of seedlings and creating moribund root systems (Prospero et al. 2006).

In central and northern Europe, A. borealis co-occurs sympatrically in coniferous or mixed forests with one or both A. ostoyae 
or A. cepistipes (Bendel et al. 2006a; Keca and Solheim 2011; Korhonen 1978; Legrand et al. 1996; Prospero et al. 2003; Siepmann 1985). All three species are commonly associated with Norway spruce (Picea abies (L.) Karst.) (Keca and Solheim 2011; Korhonen 1978; Marxmüller et al. 1990; Prospero et al. 2003). In a previous inoculation experiment, it was shown that $A$. ostoyae is pathogenic on Norway spruce, with significant differences among isolates in virulence, whereas A. cepistipes is only weakly pathogenic (Prospero et al. 2004). In the present study, we determine the pathogenic potential of several A. borealis isolates as well as their ability to colonize fresh stumps. For comparison purposes, A. ostoyae and A. cepistipes isolates, whose virulence on Norway spruce was determined in a previous study (Prospero et al. 2004), were included in the experiment. Specifically, we (i) assessed the virulence of $A$. borealis on Norway spruce seedlings of two different ages and compared it with that of A. ostoyae and A. cepistipes, and (ii) determined the ability of these three species to colonize fresh stumps.

\section{Materials and Methods}

Armillaria spp. isolates. The virulence of 10 A. borealis, nine A. ostoyae, and five A. cepistipes isolates (Table 1) toward Norway spruce was determined. All isolates originated from Switzerland and were collected between 1992 and 1999, with the exception of A. borealis isolates A1 and A2, which were collected in 2010 and 2011 , respectively. The A. borealis isolates were selected to represent different forest types and sites with varying altitudes (425 to 1,900 meters above sea level [m a.s.1.]) distributed throughout all of Switzerland. Seven A. borealis isolates were recovered from soil rhizomorphs, two from mycelial fans on infected trees, and one from a fruiting body. The A. cepistipes isolates were a random selection of those already characterized by Prospero et al. (2004). Similarly, the

Table 1. Isolates of Armillaria borealis, A. cepistipes, and A. ostoyae used in this study

\begin{tabular}{|c|c|c|c|c|c|c|c|c|}
\hline \multirow[b]{2}{*}{ Isolate $^{\mathbf{a}}$} & \multirow{2}{*}{$\begin{array}{l}\text { Lab designation } \\
\text { (WSLCC no.) }^{\mathbf{b}}\end{array}$} & \multirow[b]{2}{*}{ Source $^{c}$} & \multirow[b]{2}{*}{ Origind $^{d}$} & \multicolumn{2}{|c|}{ Coordinates } & \multirow[b]{2}{*}{ Altitude $^{\mathrm{e}}$} & \multirow{2}{*}{$\begin{array}{l}\text { Year of } \\
\text { isolation }\end{array}$} & \multirow{2}{*}{$\begin{array}{c}\text { GenBank accession } \\
\text { no. EF-1 } \alpha\end{array}$} \\
\hline & & & & East & North & & & \\
\hline \multicolumn{9}{|c|}{ A. borealis } \\
\hline A1 & RH415 (M9252) & RS & $\begin{array}{l}\text { Coniferous forest with } P \text {. abies } \\
\text { and Larix decidua }\end{array}$ & 9.6498 & 46.3630 & 1,270 & 2010 & KX712847 \\
\hline A2 & RH521/F (M9253) & $\mathrm{F}$ & P. abies (stump) & 8.4541 & 47.3629 & 541 & 2011 & KX712849 \\
\hline A3 & $\begin{array}{l}\text { LWF NAT tree no. } 5564 \\
\text { (M9254) }\end{array}$ & M & Pinus mugo & 10.2301 & 46.6625 & 1,900 & 1999 & KX712852 \\
\hline A4 & LWF ALP 8-2 (M4474) & RS & $\begin{array}{l}\text { Coniferous forest dominated by } \\
\text { P. abies }\end{array}$ & 8.7126 & 47.0486 & 1,160 & 1994 & KX712851 \\
\hline A5 & PBMD 4410 (M5240) & M & Acer platanoides & 8.6573 & 47.6836 & 425 & 1996 & KX712848 \\
\hline A6 & Schwanden (M5241) & RW & P. abies (stump) & 9.1334 & 46.9934 & 820 & 1995 & KX712853, KX712856 f \\
\hline A7 & 722201/2-3 (M5223) & $\mathrm{RS}$ & $\begin{array}{l}\text { Mixed forest with Fagus sylvatica } \\
\text { among others }\end{array}$ & 9.0413 & 46.9489 & 985 & 1997 & JN657497g \\
\hline A8 & 654245/1-1 (M9255) & RS & Mixed forest dominated by $P$. abies & 8.1534 & 47.3536 & 475 & 1992 & KX712850 \\
\hline A9 & 522161/b (M9256) & $\mathrm{RS}$ & $\begin{array}{l}\text { Mixed forest dominated by } \\
F . \text { sylvatica }\end{array}$ & 6.4207 & 46.5957 & 600 & 1993 & KX712854, KX712855 f \\
\hline A10 & 618229/2-2 (M9257) & RS & $\begin{array}{l}\text { Mixed forest dominated by } \\
\text { P. abies }\end{array}$ & 7.6762 & 47.2117 & 479 & 1992 & KX712857, KX712858f,h \\
\hline \multicolumn{9}{|c|}{ A. cepistipes } \\
\hline B2 & LWF LAU 1-1 (M9258) & RS & $\begin{array}{l}\text { Broadleaf forest dominated by } \\
\text { F. sylvatica }\end{array}$ & 6.6580 & 46.5838 & 807 & 1998 & KX712859 \\
\hline B7 & 498145/1-1 (M9259) & RS & $\begin{array}{l}\text { Coniferous forest with } P \text {. abies } \\
\text { and } A \text {. alba }\end{array}$ & 6.1111 & 46.4486 & 1,230 & 1997 & KX712860 \\
\hline B8 & 730233/3-2 (M9260) & RS & $\begin{array}{l}\text { Mixed forest with } P \text {. abies and } \\
\text { A. alba }\end{array}$ & 9.1556 & 47.2351 & 940 & 1997 & KX712861 \\
\hline B13 & 586225/2-2 (M9261) & RS & $\begin{array}{l}\text { Mixed forest with } P \text {. abies and } \\
F \text {. sylvatica }\end{array}$ & 7.2539 & 47.1758 & 882 & 1997 & KX712862 \\
\hline B16 & 746177/1-1 (M9262) & RS & $\begin{array}{l}\text { Coniferous forest with } P \text {. abies } \\
\text { and } L \text {. decidua }\end{array}$ & 9.3488 & 46.7282 & 1,570 & 1997 & KX712863 \\
\hline \multicolumn{9}{|c|}{ A. ostoyae } \\
\hline C1 & 562177/1 (M4396) & RS & Mixed forest dominated by $P$. abies & 6.9414 & 46.7431 & 740 & 1997 & KX712864 \\
\hline $\mathrm{C} 2$ & LWF LAU 10 (M4397) & RS & $\begin{array}{l}\text { Mixed forest dominated by } \\
F . \text { sylvatica }\end{array}$ & 6.6580 & 46.5838 & 807 & 1998 & KX712865 \\
\hline C6 & LWF CHI 23-3 (M4401) & RS & $\begin{array}{l}\text { Coniferous forest dominated by } \\
\text { P. abies }\end{array}$ & 8.8122 & 46.4468 & 1,364 & 1996 & KX712866 \\
\hline $\mathrm{C} 7$ & 498145/3-2 (M4402) & RS & $\begin{array}{l}\text { Coniferous forest with } P \text {. abies } \\
\text { and } A \text {. alba }\end{array}$ & 6.1111 & 46.4486 & 1,230 & 1997 & KX712867 \\
\hline $\mathrm{C} 10$ & 722201/1-2 (M4404) & $\mathrm{RS}$ & $\begin{array}{l}\text { Mixed forest with } F \text {. sylvatica } \\
\text { among others }\end{array}$ & 9.0413 & 46.9489 & 985 & 1997 & KX712868 \\
\hline $\mathrm{C} 14$ & PBMD 4723 (M4407) & M & P. abies & 9.1343 & 47.5383 & 485 & 1997 & KX712869 \\
\hline $\mathrm{C} 15$ & PBMD 4678 (M4408) & M & Pinus sylvestris & 8.3012 & 47.4097 & 420 & 1996 & KX712870 \\
\hline $\mathrm{C} 16$ & PBMD 4793 (M4409) & M & Pseudotsuga menziesii & 8.6392 & 47.6815 & 400 & 1997 & KX712871 \\
\hline $\mathrm{C} 18$ & PBMD 3933 (M4411) & M & P. abies & 8.4435 & 47.5071 & 520 & 1995 & KX712872 \\
\hline
\end{tabular}

a Reference for isolates B2 to B16 and C1 to C18 is Prospero et al. 2004.

${ }^{\mathrm{b}}$ M-numbers in parentheses refer to the Swiss Federal Research Institute WSL Phytopathology culture collection (WSLCC).

${ }^{\mathrm{c}} \mathrm{F}$, fruiting body; M, mycelial fan; RS, rhizomorph from soil; and RW, rhizomorph from wood.

${ }^{\mathrm{d}}$ For rhizomorph samples collected from soil, the forest type is given.

e Meters above sea level.

${ }^{\mathrm{f}}$ Because of indels, the two alleles are given as separate sequences.

gequenced by Tsykun et al. (2013).

${ }^{\mathrm{h}}$ A former version of this sequence (a combination of the two alleles) was uploaded to GenBank by Tsykun et al. (2013), accession no. JN657496. 
nine A. ostoyae isolates were chosen to represent the complete virulence spectrum of this species observed by Prospero et al. (2004). Species identity of all isolates was confirmed by sequencing a part of the gene encoding the translational elongation factor $1 \alpha(\mathrm{EF}-1 \alpha)$ as described in Heinzelmann and Rigling (2016). GenBank accession numbers are given in Table 1 . In addition, the A. borealis isolates were paired with three haploid tester strains (Korhonen 1978) of A. borealis and A. ostoyae, as described by Harrington et al. (1992). Based on microsatellite markers (Heinzelmann and Rigling 2016), all 24 Armillaria spp. isolates represented different genotypes. All isolates were maintained on $2 \%$ malt extract agar (20 g of Diamalt (Hefe Schweiz AG, Stettfurt, Switzerland), $15 \mathrm{~g}$ of plant propagation agar, 1 liter of deionized water) at $4^{\circ} \mathrm{C}$. Before the start of the experiment, fresh cultures of all isolates were set up.

Preparation of inoculum. The inoculum was prepared as described in Prospero et al. (2004). Briefly, fresh stem segments $(10 \times 3$ to $4 \mathrm{~cm}$ in diameter) of common hazel (Corylus avellana L.) were put in 1-liter polypropylene jars with screwable top lids containing $200 \mathrm{ml}$ of wood chips (1:1 mixture of Norway spruce and common hazel wood) and $200 \mathrm{ml}$ of deionized water. The jars with the stem segments were then autoclaved twice for $30 \mathrm{~min}$, before inoculation with Armillaria spp. As inoculum, two small plugs of a growing Armillaria culture were placed on the wood chips in each jar. To allow thorough colonization of the stem segments, the jars were incubated for 4 months at $25^{\circ} \mathrm{C}$ in the dark.

Host plants. Virulence of Armillaria spp. was tested on seedlings ( 2 years old) and saplings (4 years old) of Norway spruce. The seedlings and saplings were grown from seeds originating from two provenances in the Swiss Plateau (Birmenstorf AG, $8.2853^{\circ} \mathrm{E}, 47.4462^{\circ} \mathrm{N}$, $400 \mathrm{~m}$ a.s.l. and Bremgarten, $8.3083^{\circ} \mathrm{E}, 47.3607^{\circ} \mathrm{N}, 425 \mathrm{~m}$ a.s.l.). In April 2013, the field-grown seedlings and saplings were uprooted and transferred to 3.5- and 10-liter pots. The soil substratum was composed of $33 \%$ wood fiber material (Ökohum $\mathrm{GmbH}$, Herrenhof, Switzerland), 67\% "container soil" (42\% bark humus, $42 \%$ peat, $12 \%$ wood fibers, $4 \%$ clay, NPK-fertilizer with trace elements; Ökohum $\mathrm{GmbH}$ ) supplemented with (per liter) $2 \mathrm{~g}$ of a pattern-release fertilizer (Osmocote plus Standard 8-9 months; Everris International B.V.P.O., Geldermalsen, The Netherlands), $1 \mathrm{~g}$ of "Unikorn I" (Hauert HBG Dünger AG, Grossaffoltern, CH), and $2 \mathrm{~g}$ of horn meal. Five seedlings were planted in each 3.5-liter pot, whereas the saplings were planted individually in 10-liter pots. A section of a plastic pipe (3 $\mathrm{cm}$ in diameter, $20 \mathrm{~cm}$ in length) was buried in the rooting zone of the seedlings and saplings to accommodate the Armillaria inoculum (Prospero et al. 2004). In April 2014, 2 g of the slow-release fertilizer Tardit-Top (Hauert HBG Dünger AG) per liter were added to each pot. Seedlings and saplings were watered as required.

Seedling inoculation. At the beginning of June 2013, 6 weeks after potting, the seedlings and saplings were inoculated with Armillaria spp. As described by Prospero et al. (2004), the plastic pipe in each pot was removed and was replaced by a stem segment colonized by Armillaria spp. Eight pots, each containing five seedlings, and 20 pots with one sapling, each, were inoculated with each Armillaria isolate. Similarly, noninoculated, autoclaved stem segments were placed in eight 3.5-liter and 2010 -liter pots as negative controls. The pots with the seedlings were arranged in a randomized block design in the forest nursery of the Swiss Federal Research Institute WSL (Birmensdorf, Switzerland). Each of the eight blocks contained one pot per Armillaria isolate. Similarly, the pots with the saplings were allocated to five blocks and randomized within blocks, with each block containing four pots of each Armillaria isolate.

Stump creation. To assess the ability of the tested Armillaria isolates to colonize fresh stumps, half of the surviving saplings at the beginning of the third growing season were selected to simulate "mini-stumps". On April 29, 2015 (i.e., 23 months after inoculation) the then 6-year-old saplings were cut $15 \mathrm{~cm}$ above the soil level. For each tested Armillaria isolate, about 10 stumps (usually two per block) were produced, sometimes fewer, depending on the mortality observed until the time point of cutting.
Assessment of virulence and stump colonization. After inoculation, the seedlings and saplings were regularly assessed for symptoms of Armillaria root disease (i.e., wilting, discoloration of needles, defoliation, and mortality) during three growing seasons (June 2013 to November 2015). The assessments were done biweekly during the growing period (March to October) and monthly during wintertime (November to February). At each assessment, the symptomatic and dead seedlings and saplings were recorded. Dead seedlings and saplings were then examined for the presence of subcortical mycelial fans of Armillaria spp. in the root collar region but were not removed from the pots.

In November 2015-that is 29 months after pot inoculation and 6 months after creation of the stumps-the root collars of the asyet-unexamined seedlings and saplings and of all stumps were inspected for the presence of Armillaria lesions characterized by one or both strong resinosis or mycelial fans in the cambial region. Seedlings and saplings were classified as healthy (absence of Armillaria lesions or mycelial fans), infected (presence of Armillaria lesions at the root collar, less than $100 \%$ of the root collar girdled by mycelial fans), and dead (dead, $100 \%$ girdled root collar). Stumps were categorized either as colonized (mycelial fans present) or not colonized (mycelial fans absent).

Rhizomorph production. Rhizomorph production of Armillaria spp. was estimated by adapting the method described by Prospero et al. (2004). Briefly, the root ball was removed from the pot and its external surface was examined for rhizomorphs. Visible rhizomorphs were quantified as follows: $0=$ rhizomorphs absent, $1=$ one rhizomorph visible, 2 = at least two rhizomorphs present in different locations on the root ball, and $\leq 75 \%$ of the root ball covered with a rhizomorph network, and $3=>75 \%$ of the root ball covered by a rhizomorph network. Thereafter, the root ball was split in half with an axe to expose the rhizomorphs in the interior of the root ball, which were quantified using the following scale: $0=$ rhizomorphs absent, $1=$ rhizomorphs growing out from one spot of the inoculum, at least one rhizomorph visible, 2 = rhizomorphs growing out from two to four locations from the inoculum, $\leq 75 \%$ of the inoculum with a rhizomorph network, and $3=>75 \%$ of the inoculum covered by a rhizomorph network. For each pot, the mean rhizomorph production was calculated as the average of the exterior and interior estimate and was used for further analyses. This detailed rhizomorph assessment was only conducted for the seedlings. In pots containing the saplings and the stumps, only the presence or absence of rhizomorphs in the root ball was recorded. If rhizomorphs were absent in a pot, the viability of the inoculum segment was verified. For this, the inoculum segment was split lengthwise and the two halves were incubated in a moist chamber at room temperature. The presence of Armillaria in the inoculum was indicated by outgrowth of the typical brushes of aerial hyphae after about 1 week of incubation.

Armillaria spp. reisolation. Armillaria spp. were reisolated from a subset of dead seedlings and saplings and a subset of colonized stumps, to verify that they were infected by the inoculated Armillaria isolates. Bark and wood samples were taken from the root collar or stem so that the subcortical mycelial fans were sandwiched between bark and wood. Subsequently, in the laboratory, small pieces of mycelium (about $1 \times 2$ to $5 \mathrm{~mm}$ ) were carefully removed from the cambial zone using sterilized forceps and a scalpel. The obtained mycelium was placed on Maloy's medium (12 g of Bacto malt extract, $15 \mathrm{~g}$ of plant propagation agar, 1 liter of deionized water supplemented with $2 \mathrm{mg}$ of benomyl and $100 \mathrm{mg}$ streptomycin, based on Maloy [1974]), without any surface sterilization. All isolation plates were incubated at room temperature and, after 5 to 10 days, a small portion of growing mycelium was transferred to $2 \%$ malt extract agar. For A. borealis and A. cepistipes, one infected seedling or sapling per pot with mortality was sampled, whereas for A. ostoyae, the sampling was done for each isolate in at least half of the pots with mortality. Similarly, stump sampling was done for all three species from at least half of the colonized stumps per isolate.

Pairing tests. The identity of all reisolates was verified in somatic pairings with the reference isolates used for inoculation. Pairings were conducted on Shaw and Roth's medium (40 g of Diamalt, 
$20 \mathrm{~g}$ of D-[+]-glucose, $5 \mathrm{~g}$ Bacto peptone, $15 \mathrm{~g}$ of plant propagation agar, 1 liter of deionized water, based on Shaw and Roth [1976] as described by Harrington et al. [1992]). Culture morphology of the pairings was assessed after 4 to 6 weeks. Pairings were rated as compatible when the paired isolates merged and grew as one homogenous colony and no barrage line was visible.

Statistical analysis. All statistical analyses were performed with $\mathrm{R}$ (R Development Core Team 2016). The two A. ostoyae isolates C14 and $\mathrm{C} 15$ were excluded from calculation of species means and comparative analyses in the sapling and stump experiment and the seedling and sapling and stump experiments, respectively, because fewer than $50 \%$ of the seedlings or saplings were exposed to rhizomorphs. To account for the reduced sample size after cutting half of the saplings 23 months after inoculation, only half of the saplings killed until this time point were included in subsequent assessments of the noncut group.

Rhizomorph production among species was compared using a Kruskal-Wallis rank sum test. For the calculation of the rhizomorph production per isolate, pots without rhizomorphs were also considered. The relationship between rhizomorph production and virulence in the seedlings experiment as well as the relationship between virulence, i.e., the number of killed plus infected saplings by the end of the experiment, and stump colonization in the sapling experiment were examined by calculating the Pearson's product-moment correlation coefficient. The correlation of virulence in A. borealis and A. ostoyae between the seedling and sapling experiments was tested using the same coefficient.

Virulence of $A$. borealis and A. ostoyae in the seedling and sapling experiments was compared using a generalized linear mixed model, with a logit link function and a binomial error distribution as implemented in the package 'Ime4' (Bates et al. 2015). For each of the two experiments, a separate model was fitted. Seedling or sapling status (i.e., dead or infected, or alive) at the end of the experiment was considered as the response variable. The basic model included species as fixed effect and isolate and block as random effects. In addition, pot was included as random effect in the model for the seedling experiment, because five trees were contained within a single pot. The variable isolate was nested within species and the variable pot within block. The accuracy of the model fit was assessed with TukeyAnscombe plots, generated by plotting the Pearson residuals against the linear predictor. The significance of the random effect of "isolate" was evaluated using a likelihood ratio test.

Because of the low incidence of mortality in A. cepistipes (discussed below), this species could not be included in the model. Similarly, because of the high incidence of colonized stumps in general, and especially in A. ostoyae (discussed below), no reliable statistical comparison of stump colonization among the three species could be made.

\section{Results}

Viability of inocula and rhizomorph production. In both experiments, all inocula originating from pots without rhizomorphs were viable, indicating that all inocula still contained living Armillaria spp. at the end of the experiments. In pots with seedlings, $91 \%$ (171 of 187) of the inocula produced rhizomorphs. Individual inocula failed to produce rhizomorphs in one A. borealis isolate (A5) and in two A. ostoyae isolates (C2, C6). None of the inocula colonized by the $A$. ostoyae isolate $\mathrm{C} 15$ produced rhizomorphs. In contrast, all A. cepistipes isolates produced rhizomorphs. The mean rhizomorph production (Table 2 ) was highest for A. cepistipes $(2.25 \pm 0.32$, mean \pm standard deviation) and lowest for A. ostoyae $(1.77 \pm 0.51)$. The mean rhizomorph production of $A$. borealis was $2.01 \pm 0.25$. However, these differences among species were statistically not significant $\left(\chi^{2}=3.50\right.$, $\mathrm{df}=2, P=0.175$ ).

In the pots with saplings, $84 \%$ (400 of 478 ) of the inocula produced rhizomorphs. As in the other experiment, inocula of A. cepistipes always produced rhizomorphs. The two A. ostoyae isolates $\mathrm{C} 14$ and $\mathrm{C} 15$ were again poor rhizomorph producers, with only $35 \%$ and $20 \%$ of the inocula having rhizomorphs, respectively (Supplementary Table S2). Rhizomorph formation was also reduced in the $A$. borealis isolates A5, A8, A9, and the A. ostoyae isolates C2, C6, C16, where only 55 to $80 \%$ of the inocula produced rhizomorphs. In all other isolates, rhizomorphs were produced from at least $90 \%$ of the inocula.

Virulence. In both experiments, A. borealis and A. ostoyae caused only sporadic mortality until the second growing season (Figs. 1 and 2). Afterward, mortality steadily increased in these two species. A. cepistipes did not cause any mortality in the sapling experiment and only a few seedlings had been killed by A. cepistipes in the seedling experiment by its end (Table 2). During winter (December to February), seedling mortality was low. An increased mortality was observed in March and April and a peak was reached in summer and autumn (June to October).

In the seedling experiment, onset of substantial mortality was earlier with $A$. borealis than with A. ostoyae (Table 2). After 17 and 23 months, the percentage of killed seedlings in A. borealis was about twice as high as in A. ostoyae. In the third growing season, however, mortality of $A$. ostoyae began to approach that caused by $A$. borealis and, by the end of the experiment (i.e., 29 months postinoculation), the percentage of killed seedlings was similar $(P=$ $0.467)$ in both species (41.0\% in A. borealis, $37.1 \%$ in A. ostoyae). The percentage of infected but not yet killed seedlings was low for

Table 2. Incidence of Norway spruce (Picea abies) plants killed 11, 17, 23, and 29 months after inoculation with Armillaria spp. as well as the number of plants still alive but infected after 29 months

\begin{tabular}{|c|c|c|c|c|c|c|c|c|c|}
\hline \multirow[b]{2}{*}{ Species } & \multirow[b]{2}{*}{ No. of isolates } & \multirow[b]{2}{*}{ No. inoc. ${ }^{a}$} & \multirow[b]{2}{*}{ Exposed $^{b}$} & \multirow[b]{2}{*}{11 months $^{\mathrm{c}}$} & \multirow[b]{2}{*}{17 months ${ }^{c}$} & \multirow[b]{2}{*}{23 months ${ }^{c}$} & \multicolumn{2}{|c|}{29 months ${ }^{c}$} & \multirow[b]{2}{*}{ Rhizomorph production ${ }^{d}$} \\
\hline & & & & & & & Killed & Infected & \\
\hline \multicolumn{10}{|c|}{ Experiment with 2-year-old seedlings } \\
\hline A. borealis & 10 & 395 & $390(98.7 \%)$ & $1(0.3 \%)$ & $41(10.5 \%)$ & $91(23.3 \%)$ & $160(41.0 \%)$ & $4(1.0 \%)$ & $2.01(0.25)$ \\
\hline A. ostoyae & $8^{\mathrm{e}}$ & 310 & $275(88.7 \%)$ & $0(0.0 \%)$ & $12(4.4 \%)$ & $32(11.6 \%)$ & $102(37.1 \%)$ & $2(0.7 \%)$ & $1.77(0.51)$ \\
\hline A. cepistipes & 5 & 190 & $190(100.0 \%)$ & $0(0.0 \%)$ & $0(0.0 \%)$ & $0(0.0 \%)$ & $4(2.1 \%)$ & $0(0.0 \%)$ & $2.25(0.32)$ \\
\hline \multicolumn{10}{|c|}{ Experiment with 4-year-old saplings } \\
\hline A. borealis & 10 & 199 & $174(87.4 \%)$ & $2(1.1 \%)$ & $10(5.7 \%)$ & $15(8.6 \%)$ & $12^{\mathrm{f}}(13.2 \%)$ & $11(12.6 \%)$ & $\mathrm{Nd}$ \\
\hline A. ostoyae & $7 \mathrm{~g}$ & 139 & $115(82.7 \%)$ & $0(0.0 \%)$ & $7(6.1 \%)$ & $11(9.6 \%)$ & $14^{\mathrm{f}}(23.6 \%)$ & $7(12.3 \%)$ & $\mathrm{Nd}$ \\
\hline A. cepistipes & 5 & 100 & $100(100.0 \%)$ & $0(0.0 \%)$ & $0(0.0 \%)$ & $0(0.0 \%)$ & $0(0.0 \%)$ & $0(0.0 \%)$ & $\mathrm{Nd}$ \\
\hline
\end{tabular}

${ }^{a}$ Number of seedlings or saplings contained in pots with a buried inoculum segment.

${ }^{b}$ Number (percentage) of exposed seedlings or saplings = seedlings or saplings in pots with rhizomorphs.

c Cumulative number (percentage) of exposed seedlings or saplings killed or infected by Armillaria spp.

${ }^{\mathrm{d}}$ Mean (standard deviation); the mean rhizomorph production for a species was calculated by averaging the rhizomorph production over isolates within species. Rhizomorph production was scored on a 0 to 3 scale. $\mathrm{Nd}=$ not determined.

${ }^{\text {e }}$ Only isolates with at least $50 \%$ exposed seedlings were considered, therefore isolate $\mathrm{C} 15$ was excluded.

${ }^{\mathrm{f}}$ Because of stump creation 23 months after inoculation, only half of the exposed saplings (alive and dead) remained in the noncut group. The new numbers of exposed saplings were 87 for A. borealis, 57 for A. ostoyae, and 49 for A. borealis.

g Only isolates with at least $50 \%$ exposed seedlings were considered, therefore isolates $\mathrm{C} 14$ and $\mathrm{C} 15$ were excluded. 
both species ( $1.0 \%$ for $A$. borealis, $0.7 \%$ for $A$. ostoyae). In pots inoculated with $A$. cepistipes, only $2.1 \%$ of the seedlings were killed.

In $A$. borealis and $A$. ostoyae, considerable intraspecific variation in virulence was observed (seedling and sapling experiment $P<$ $0.001)$. At the end of the experiment, the percentage of killed plus infected seedlings ranged from 20 (A4) to $72.5 \%$ (A10) in A. borealis and from 10 (C14) to 60\% (C18) in A. ostoyae (Fig. 3A; Supplementary Table S1). With both Armillaria species, seedling mortality only occurred in pots with rhizomorphs. In A. ostoyae, the percentage of killed plus infected seedlings was positively correlated with rhizomorph production $(r=0.94, P<0.001)$ (Fig. 4$)$, whereas no such correlation was observed in A. borealis. In A. cepistipes, only the isolates B7, B8, and B16 were virulent (Fig. 3A).

In the sapling experiment, the percentage of killed saplings increased with A. ostoyae and A. borealis in a similar manner (Table 2). At the end of the experiment, the overall incidence of killed saplings

A
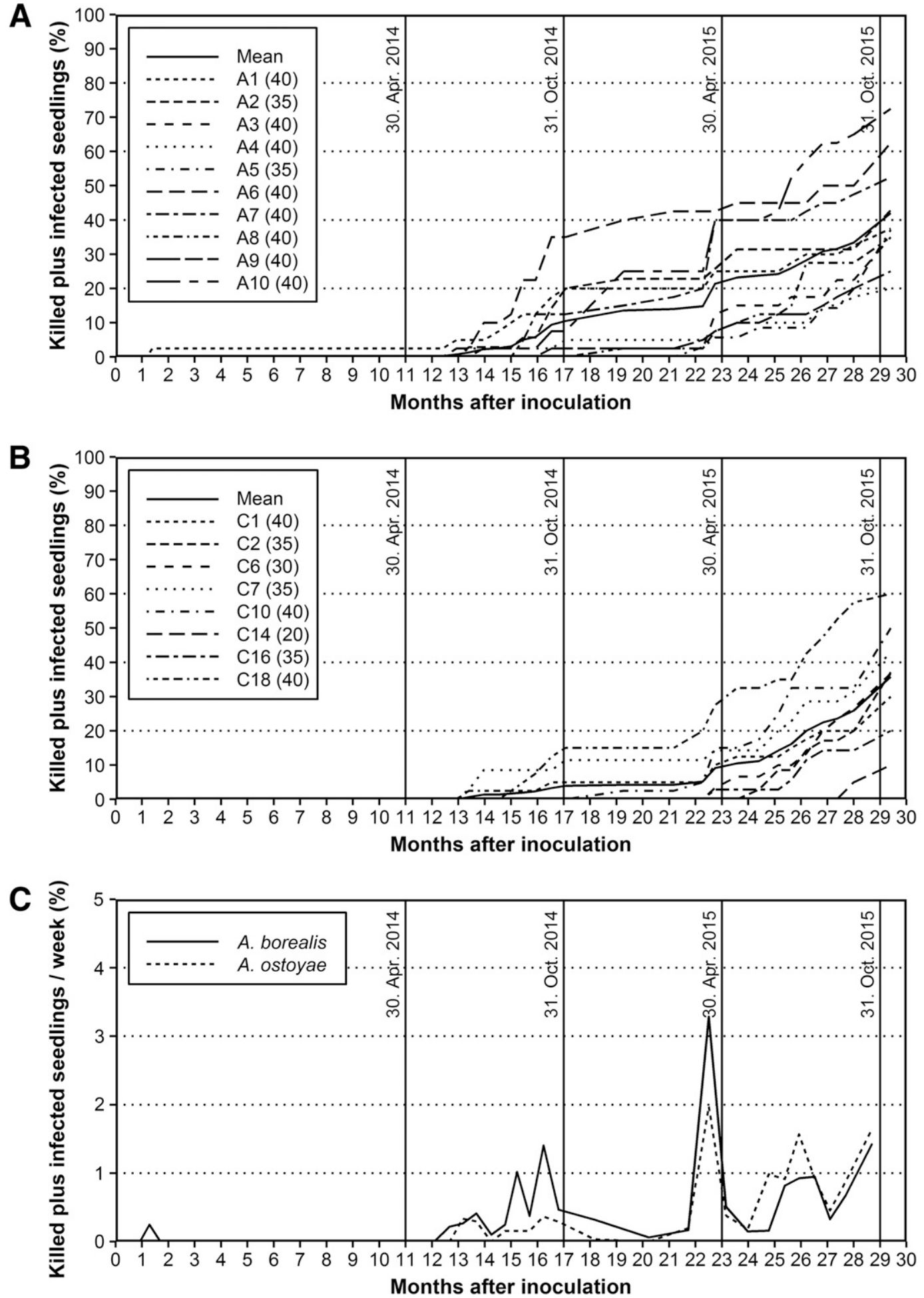

Fig. 1. Cumulative mortality of 2-year-old Norway spruce (Picea abies) seedlings during the 29 months following inoculation with $\mathbf{A}$, Armillaria borealis or $\mathbf{B}$, A. ostoyae. The last assessment also included infected but not yet killed seedlings. Isolates with less than $50 \%$ of the seedlings exposed to Armillaria spp. rhizomorphs were excluded. The number of seedlings corresponding to $100 \%$ is given in parentheses after the isolate name in the legend. C, Periodic mortality calculated as the slope of the mortality curve of the "mean" A. borealis and "mean" $A$. ostoyae isolate, respectively. 
was $23.6 \%$ in A. ostoyae and $13.2 \%$ in A. borealis; however, the difference was not statistically significant $(P=0.109)$. The percentage of infected but not yet killed saplings was similar for both species (12.3 and $12.6 \%$, respectively).

For A. ostoyae, the overall percentage of killed plus infected seedlings or saplings as well as the ranking of the different isolates were similar at the end of both experiments $(r=0.87, P=0.012)$ (Table 2; Fig. 3A and B). Isolate $\mathrm{C} 18$ showed the highest virulence and was followed by the isolates C7 and C10 (Figs. 1B and 2B). In contrast, isolates $\mathrm{C} 2, \mathrm{C} 6$, and $\mathrm{C} 16$ were only moderately or slightly virulent. Isolate $\mathrm{C} 1$ ranked higher in the sapling experiment than in the seedling experiment. The results for isolate $\mathrm{C} 14$ were inconclusive. In the seedling experiment, $\mathrm{C} 14$ was the least virulent isolate and caused very little mortality (two seedlings) toward the end of the experiment. However, in the sapling experiment, $\mathrm{C} 14$ had already killed two saplings in the first 17 months and one after stump creation, yielding
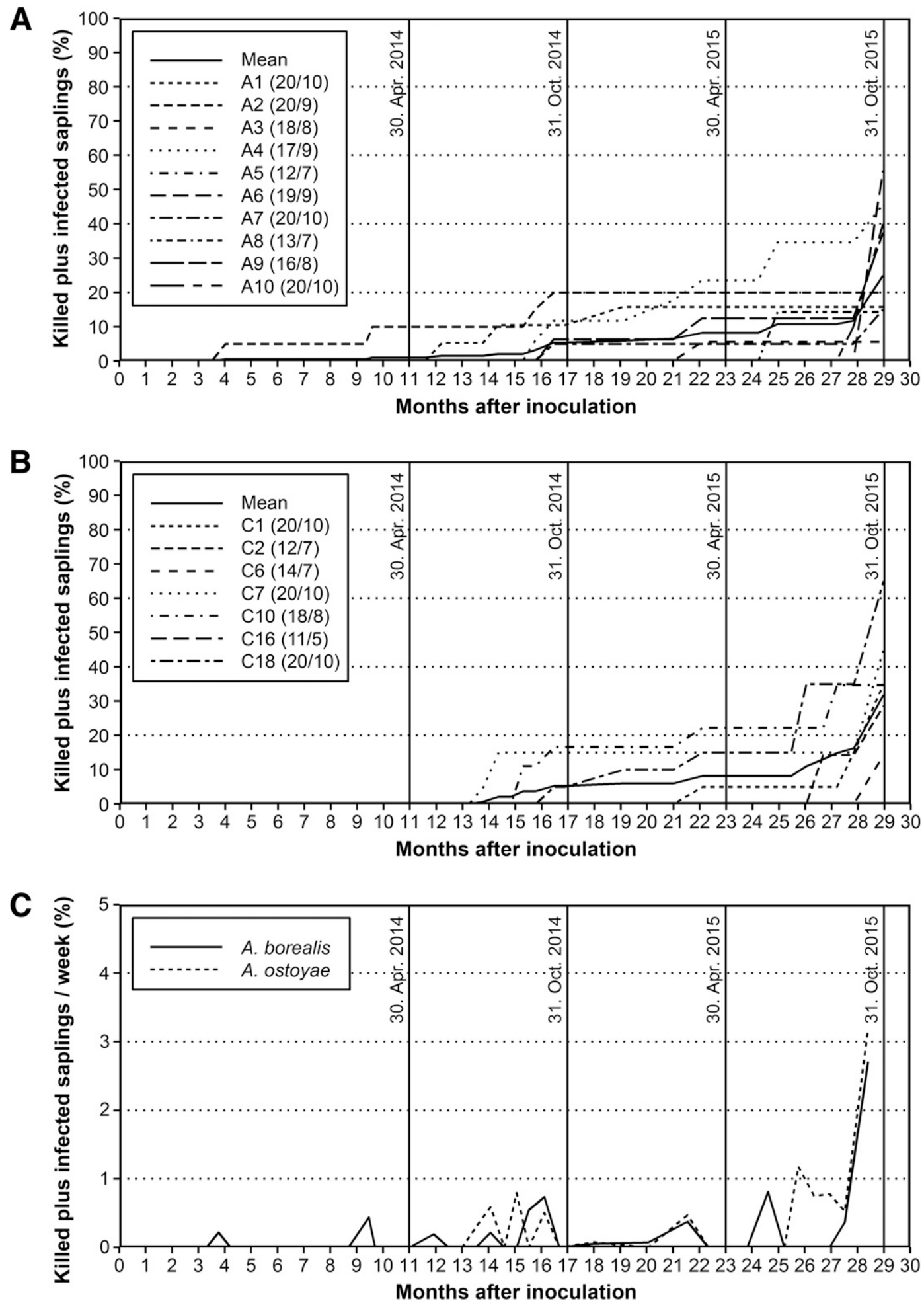

Fig. 2. Cumulative mortality of 4-year-old Norway spruce (Picea abies) saplings during the 29 months following inoculation with $\mathbf{A}$, Armillaria borealis or $\mathbf{B}, A$. ostoyae. The last assessment also included infected but not yet killed saplings. Isolates with less than $50 \%$ of the saplings exposed to Armillaria spp. rhizomorphs were excluded. The number of saplings corresponding to $100 \%$ before and after stump creation (i.e., after 23 months) is given in parentheses after the isolate name in the legend. C, Periodic mortality calculated as the slope of the mortality curve of the "mean" $A$. borealis and "mean" A. ostoyae isolate, respectively. 
$48.6 \%$ killed saplings overall. However, the number of exposed seedlings was rather low (seven out of 20).

For A. borealis, the results of the two experiments were less comparable. In the sapling experiment, the percentage of killed and infected saplings at the completion of the experiment was more than one third lower than the percentage of killed plus infected seedlings in the seedling experiment (Table 2). Moreover, the ranking of the isolates was not consistent between experiments $(r=0.25, P=0.483)$
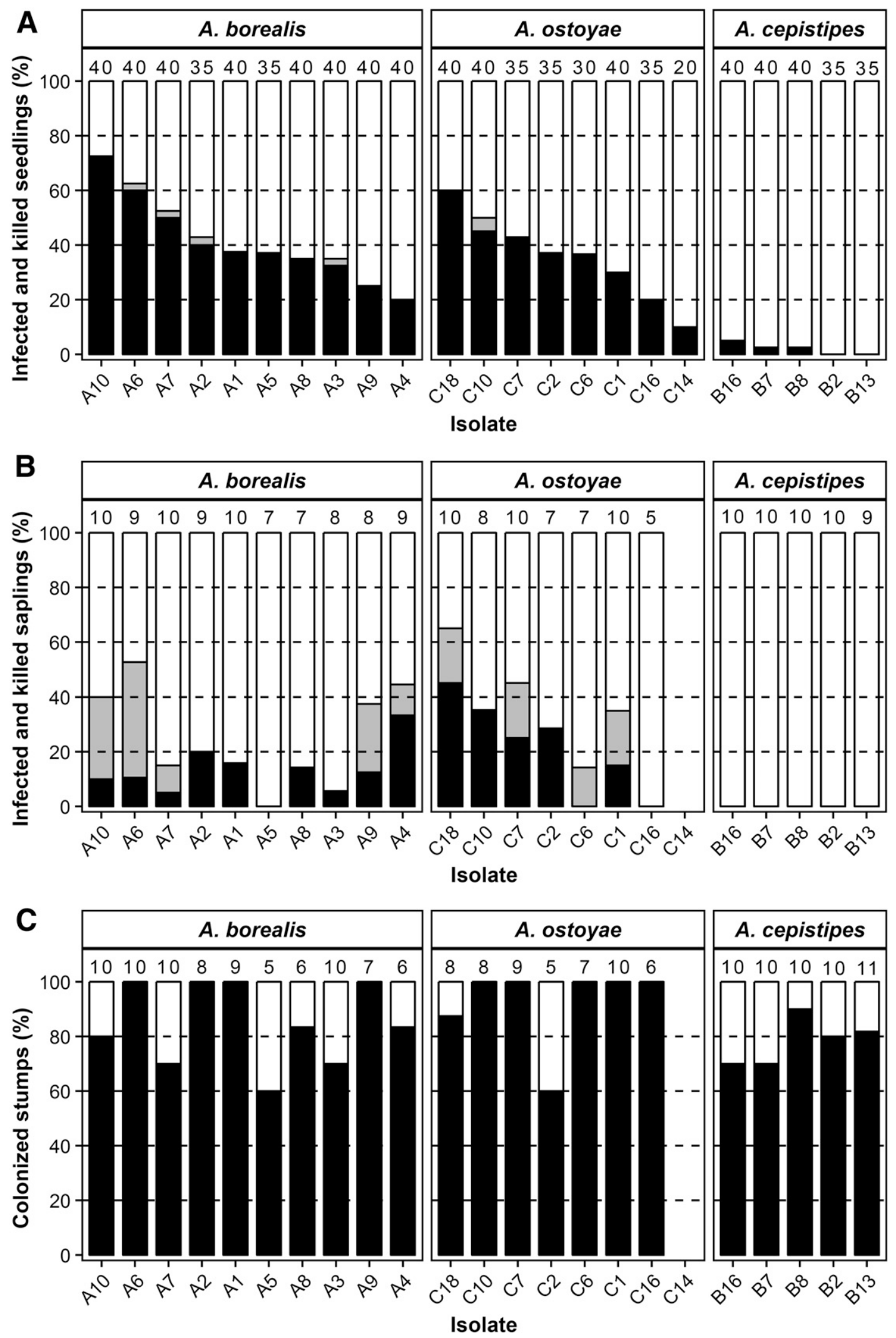

Fig. 3. Percentage of 2-year-old seedlings, 4-year-old saplings, and stumps of Norway spruce (Picea abies) colonized 29 months after inoculation with Armillaria borealis, A. ostoyae, or A. cepistipes. A, Seedlings, B, saplings (black, killed seedlings or saplings; gray, infected seedlings or saplings; white, uncolonized seedlings or saplings), and C, stumps (black, colonized stumps; white, uncolonized stumps). The number of seedlings corresponding to $100 \%$ is given on top of each bar. No bar was drawn for C14 (B and C) when less than $50 \%$ of the inoculated saplings or stumps were exposed to rhizomorphs. 
(Fig. 3A and B). In the sapling experiment, the most virulent isolates were A4, A6, A9, and A10, while isolates A4 and A9 were the least virulent in the seedling experiment.

Colonization of stumps. With all three Armillaria species, more than $78 \%$ of the exposed stumps were colonized (Table 3 ). The highest percentage of stumps was colonized by $A$. ostoyae (94.3\%), followed by A. borealis $(85.2 \%)$, and A. cepistipes (78.4\%). Among A. borealis and A. ostoyae isolates, stump colonization ranged from 60 to $100 \%$, with the exception of $A$. ostoyae isolate $\mathrm{C} 14$, in which only one stump was exposed but not colonized. Among the A. cepistipes isolates, 70 to $90 \%$ of the stumps were colonized (Fig. 3C; Supplementary Table S3). Obviously, the stump colonization ability of $A$. cepistipes was not affected by its virulence. The same applied for A. borealis and A. ostoyae. There was no significant correlation in isolate performance between the virulence experiment and the stump colonization experiment (A. borealis: $r=0.57, P=0.087$, A. ostoyae: $r=-0.15$, $P=0.746)$. Noteworthy, the species ranking was the same in both stump colonization and virulence experiments.

Out of the total of 50 unexposed stumps (including the control), $38(76 \%)$ were still alive at the completion of the experiment, as indicated by greenish bark tissue and bunches of green needles growing out of the trunk, while only 12 (24\%) were dying or dead. The bark tissue and sapwood of those stumps was discolored.

Reisolations. Armillaria was reisolated from a subsample of the infected seedlings or saplings and colonized stumps. In the seedling experiment, 102 reisolates were obtained, representing $37 \%$ of the infected seedlings and $87 \%$ of the pots with mortality. Only one of the reisolates was incompatible with the inoculated Armillaria isolate. A microsatellite analysis, as described by Heinzelmann and Rigling (2016), confirms this result and, consequently, this pot was excluded from the analyses. In the case of the sapling experiment, 36 reisolates from infected saplings and 125 from colonized stumps were obtained, representing 60 and $77 \%$ of the infected saplings and stumps, respectively. All reisolates were compatible with the corresponding original isolate used for inoculation

\section{Discussion}

The two inoculation experiments conducted in this study with 10 A. borealis, nine A. ostoyae, and five A. cepistipes isolates have demonstrated that $A$. borealis is virulent on young Norway spruce seedlings and saplings. During the first 23 months of the seedling experiment, $A$. borealis appeared even more virulent than
A. ostoyae, as evidenced by higher seedling mortality. However, 6 months later, i.e., by the end of the experiment, virulence scores were similar in both species. These results suggest that young seedlings may be highly susceptible to both $A$. borealis and A. ostoyae. However, A. borealis appears as a faster and more consistent rhizomorph producer (Guillaumin et al. 1989; Mohammed 1985; Morrison 2004), which may provide a temporal advantage over A. ostoyae in initial host infection. Indeed, in our study, seedling mortality was always associated with rhizomorph presence, but rhizomorph abundance increased seedling mortality only for A. ostoyae.

The situation was different in the sapling experiment, where virulences of A. borealis and A. ostoyae were similar for almost the entire duration of the experiment. However, by the completion of the experiment, A. ostoyae ranked higher in virulence than $A$. borealis, and the difference between the two species was more than twice that observed in the seedling experiment. The higher percentage of infected but not yet killed Norway spruce plants at the end of the sapling experiment compared with the seedling experiment suggests that older Norway spruce plants have a greater ability to withstand an attack by $A$. borealis or A. ostoyae than younger plants. The incidence of killed plus infected plants in $A$. ostoyae was rather similar in both experiments, but dropped by $16 \%$ with A. borealis in the sapling experiment. Therefore, we conclude that host resistance to A. borealis may increase more rapidly with increasing host age than resistance to A. ostoyae. From field observations, it is known that seedlings of Douglas fir (Pseudotsuga menziesii), western larch (Larix occidentalis), and maritime pine (Pinus pinaster) remain highly susceptible to $A$.

Table 3. Incidence of Norway spruce (Picea abies) stumps colonized by Armillaria spp. 6 months after their creation from 6-year-old saplings

\begin{tabular}{lcccc}
\hline & & \multicolumn{3}{c}{ Stumps } \\
\cline { 3 - 5 } Species & No. of isolates & Inoculated $^{\text {a }}$ & Exposed $^{\mathbf{b}}$ & Colonized $^{\mathbf{c}}$ \\
\hline A. borealis & 10 & 94 & $81(86.2 \%)$ & $69(85.2 \%)$ \\
A. ostoyae & $7^{\mathrm{d}}$ & 65 & $53(81.5 \%)$ & $50(94.3 \%)$ \\
A. cepistipes & 5 & 51 & $51(100.0 \%)$ & $40(78.4 \%)$ \\
\hline
\end{tabular}

a Pots containing saplings were inoculated with Armillaria spp. 23 months before stump creation.

${ }^{\mathrm{b}}$ Number (percentage) of exposed stumps = stumps in pots with rhizomorphs.

${ }^{\mathrm{c}}$ Number (percentage) of exposed stumps colonized by Armillaria spp.

${ }^{\mathrm{d}}$ Only isolates with at least $50 \%$ exposed stumps were considered, therefore isolates $\mathrm{C} 14$ and $\mathrm{C} 15$ were excluded.

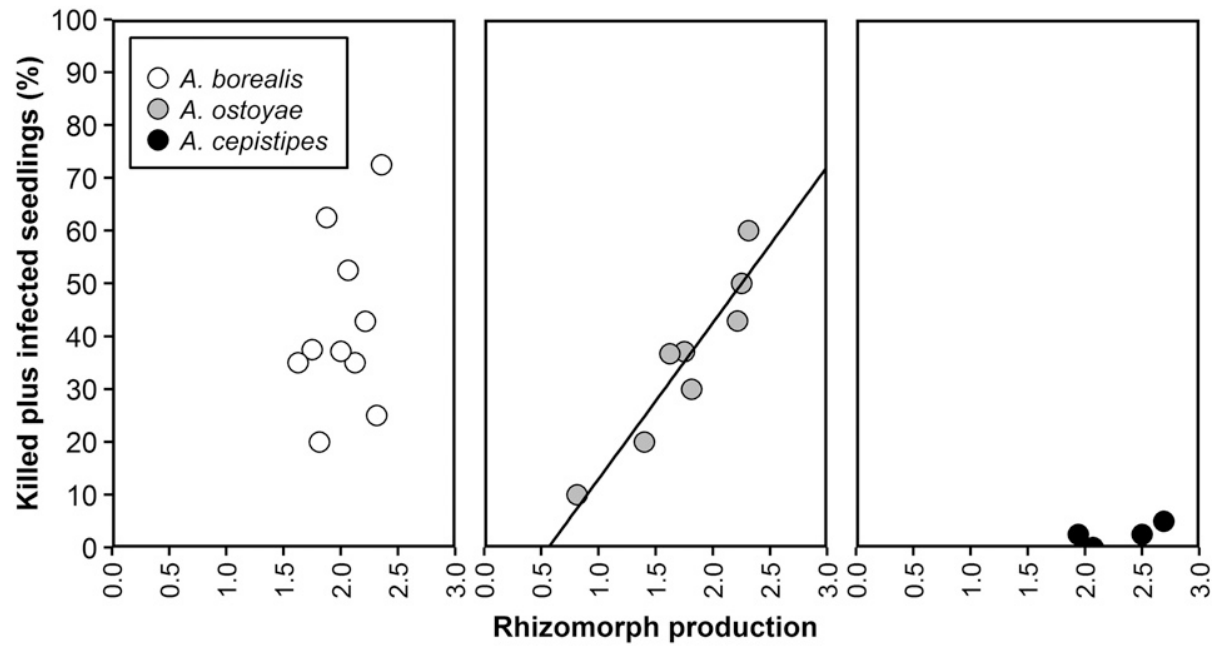

Fig. 4. Relationship between rhizomorph production and mortality plus infection of Norway spruce (Picea abies) seedlings 29 months after inoculation with Armillaria borealis, A. ostoyae, or $A$. cepistipes in the seedling experiment. For species with a significant correlation $(P>0.05)$ between the two variables, the regression line is drawn. Isolates with less than $50 \%$ of seedlings exposed to Armillaria spp. rhizomorphs were excluded. 
ostoyae up to the age of 6 to 8 years before their resistance substantially increases (Lung-Escarmant and Guyon 2004; Robinson and Morrison 2001). Further investigations with diverse hosts and a wider age range are needed to confirm that host susceptibility to A. borealis also decreases with increasing host age. Based on our results, however, we may reasonably speculate that $A$. borealis has more difficulties than $A$. ostoyae to advance to the root collar when the seedlings grow older.

To our knowledge, this is the first study that has experimentally assessed the virulence of a significant number of $A$. borealis isolates. Two prior inoculation experiments that included only a small number of isolates generated inconsistent results. The study by Morrison (2004), which included three $A$. borealis isolates, showed that $A$. borealis and $A$. ostoyae were comparable in virulence toward seedlings of Douglas fir. The seedling age ( 2 years old), experimental set up, and duration of Morrison's study were very similar to our experiment. Siepmann and Leibiger (1989) inoculated 3-year-old seedlings of Norway spruce and Scots pine (Pinus sylvestris) with two A. borealis and two A. ostoyae isolates and followed seedling survival over almost 18 months. In that study, A. borealis was clearly less virulent than $A$. ostoyae and killed fewer seedlings. However, there were many infected seedlings with root collar lesions with $A$. borealis but not with $A$. ostoyae. In both previous studies, the virulence of $A$. borealis and A. ostoyae was clearly higher than that of $A$. cepistipes or its close relative $A$. gallica. Combining these previous results with those from the present study suggests that $A$. borealis is as virulent as $A$. ostoyae when the seedlings are very young but, as the seedlings become older, $A$. borealis may become less virulent than A. ostoyae. Consequently, A. borealis could be considered the less virulent species. Previous field observations report that A. borealis, in contrast to A. ostoyae, is rarely a primary pathogen on mature trees (Gregory 1989; Gregory and Watling 1985). However, it is noteworthy that $A$. borealis is frequently reported as causing heart rot of conifers in Scandinavia (Keca and Solheim 2011; Korhonen 1978). When we cut all saplings at the end of the experiment (i.e., at the age of 6 years), we observed a dark-brown discoloration in the first growth rings in two saplings inoculated with $A$. borealis. In both cases, the presence of the inoculated isolate in the stem interior could be verified by reisolation (data not shown). This finding indicates that $A$. borealis is able to advance and spread within the central part of the stem of still young Norway spruce saplings.

Armillaria cepistipes, the third species that we included in our study, was virtually nonpathogenic on Norway spruce seedlings and saplings. No mortality was observed in the sapling experiment and just a few seedlings were killed in the seedling experiment. This is in agreement with the findings of previous experimental investigations and field observations (Gregory 1989; Guillaumin et al. 1993; Morrison 2004; Prospero et al. 2004).

Within A. borealis and A. ostoyae, considerable intraspecific variation in virulence was observed. Similar results have been obtained in previous studies with A. ostoyae (Morrison and Pellow 2002; Omdal et al. 1995; Prospero et al. 2004), whereas no comparable data are available for $A$. borealis. The rankings of the A. ostoyae isolates according to their virulence were similar in both of our inoculation experiments, with the exceptions of isolates $\mathrm{C} 1$ and $\mathrm{C} 14$, and are comparable to those obtained by Prospero et al. (2004). In the seedling experiment, the virulence of the A. ostoyae isolates was strongly correlated with their ability to produce rhizomorphs. This finding may suggest that the A. ostoyae virulence ranking could reflect the isolates' capacity to reach the host rather than its ability to invade the host. In the sapling experiment, however, when the host's vigor was strongly reduced by cutting the saplings, up to $100 \%$ of the exposed stumps were colonized by A. ostoyae, including the isolates that produced fewer rhizomorphs. Therefore, the virulence of A. ostoyae isolates likely also depends on their ability to penetrate and spread within living, vigorous tissues.

With A. borealis, isolates' virulence rankings differed considerably between the two experiments. Perhaps the conditions in the seedling experiment were so conducive to seedling infection that even less virulent isolates had ample opportunities to cause infection levels similar to the more virulent isolates, thereby obscuring differences in the virulence rankings. Alternatively, the ranking in the sapling experiment may be subject to stochastic effects, as the number of killed and infected seedlings was much lower than in the experiment with the seedlings that were two years younger.

The stumps that we created by cutting the tops of the saplings were colonized at a higher incidence than living seedlings by all three Armillaria species. Directly after cutting, the fresh stumps represent heavily stressed hosts with reduced vigor and ongoing metabolic changes (Wargo and Harrington 1991). Eventually, these stumps will die and completely lose their resistance against invading organisms. In our experiment, about $76 \%$ of the nonexposed stumps (i.e., stumps from pots in which no rhizomorphs were detected and from the control pots) were still alive 6 months after cutting, indicating that it is likely that most of the stumps were invaded by Armillaria when they were still alive. The differences in the ability to colonize the stumps among the three Armillaria species were small. The more virulent species, A. ostoyae and A. borealis, were slightly more efficient than the less virulent species A. cepistipes. This result, perhaps, indicates a greater ability of $A$. ostoyae and A. borealis to overcome residual resistance in the freshly cut stumps. Previous field observations and an experimental study also attribute a slight competitive advantage to $A$. ostoyae in stump colonization compared with A. cepistipes (Legrand et al. 1996; Prospero et al. 2003, 2006). Nevertheless, A. cepistipes, which was not able to invade any of the living saplings, colonized about $78 \%$ of the stumps. This result clearly indicates that rhizomorphs, which were consistently produced in A. cepistipes in our experiments, may not have the ability to successfully infect roots of vigorous hosts. However, once host vigor is drastically reduced (e.g., fresh stumps), the ability of $A$. cepistipes to invade compromised or moribund host tissue is similar to that of more virulent Armillaria species. Thus, our study confirms previous reports suggesting that $A$. cepistipes can act as a secondary pathogen on Norway spruce (Prospero et al. 2003, 2006).

Rhizomorphs were always present in the pots with infected seedlings, saplings, or stumps, indicating the importance of rhizomorphs in the colonization process of the three investigated Armillaria species. Nevertheless, we cannot rule out that, in a few cases, the infection was mediated by direct contact of the inoculum segment with roots.

With a few exceptions, the Armillaria isolates included in our study were isolated 14 to 21 years before the start of the experiments. Morrison and Pellow (2002) found that the virulence of A. ostoyae isolates decreases with time after isolation. The virulence of our $A$. ostoyae and A. cepistipes isolates was assessed in a similar inoculation experiment on 2-year-old Norway spruce seedlings almost 15 years ago by Prospero et al. (2004). In contrast to the findings of Morrison and Pellow (2002), seedling mortality plus infection with A. ostoyae, in our experiment, was higher than that observed in the previous study by Prospero et al. (2004). Thus, our results suggest that at least some Armillaria isolates maintain their virulence over longer periods of time when stored at $4^{\circ} \mathrm{C}$ on malt agar.

In conclusion, our study shows that $A$. borealis is pathogenic toward Norway spruce, and hence, possibly other conifers. When trees are very young ( 1 to 3 years), A. borealis can be as virulent as $A$. ostoyae. In the context of a natural forest ecosystem, this could mean that $A$. borealis may cause mortality within young, natural regeneration; however, further field investigations are needed to confirm this hypothesis. In contrast, older seedlings seem to be less susceptible to A. borealis than to A. ostoyae. Consequently, A. borealis is expected to cause less damage than A. ostoyae on mature trees, as confirmed by previous field observations (Gregory 1989; Gregory and Watling 1985). Nevertheless, compared with A. cepistipes, a virtually nonpathogenic species, A. borealis is clearly more relevant as a pathogen. Despite important differences in primary parasitism among $A$. borealis, A. ostoyae, and A. cepistipes, all three species show a comparable ability to act as secondary pathogens and infect strongly debilitated trees. 


\section{Acknowledgments}

We thank A. Burkart, G. Reiss, C. Cattaneo, P. Suter, and P. Schweizer of the forest nursery of the Swiss Federal Research Institute WSL for providing the plant material, their technical and logistics assistance in setting up the field plot, and for their assistance in watering the seedlings. We are grateful to $\mathrm{H}$. Vydrzel for her help in planting and inoculating the seedlings, and E. Jung, H. Blauenstein, B. Meier, and K. Kleeb for their support in the laboratory. We also thank O. Holdenrieder and three anonymous reviewers for the constructive comments on the manuscript and C. Gautschi for the English revision.

\section{Literature Cited}

Asef, M. R., Goltapeh, E. M., and Alizadeh, A. 2003. Identification of Armillaria biological species in Iran. Fungal Divers. 14:51-60.

Bates, D., Mächler, M., Bolker, B., and Walker, S. 2015. Fitting linear mixedeffects models using lme4. J. Stat. Softw. 67:1-48.

Baumgartner, K., Coetzee, M. P. A., and Hoffmeister, D. 2011. Secrets of the subterranean pathosystem of Armillaria. Mol. Plant Pathol. 12:515-534.

Bendel, M., Kienast, F., Bugmann, H., and Rigling, D. 2006b. Incidence and distribution of Heterobasidion and Armillaria and their influence on canopy gap formation in unmanaged mountain pine forests in the Swiss Alps. Eur. J. Plant Pathol. 116:85-93.

Bendel, M., Kienast, F., and Rigling, D. 2006a. Genetic population structure of three Armillaria species at the landscape scale: A case study from Swiss Pinus mugo forests. Mycol. Res. 110:705-712.

Brazee, N. J., Hulvey, J. P., and Wick, R. L. 2011. Evaluation of partial tef1, rpb2, and $n L S U$ sequences for identification of isolates representing Armillaria calvescens and Armillaria gallica from northeastern North America. Fungal Biol. 115:741-749.

Coetzee, M. P. A., Bloomer, P., Wingfield, M. J., and Wingfield, B. D. 2011. Paleogene radiation of a plant pathogenic mushroom. PLoS One 6:e28545.

Collins, C., Keane, T. M., Turner, D. J., O'Keeffe, G., Fitzpatrick, D. A., and Doyle, S. 2013. Genomic and proteomic dissection of the ubiquitous plant pathogen, Armillaria mellea: Toward a new infection model system. J. Proteome Res. 12:2552-2570.

Gregory, S. C. 1989. Armillaria species in northern Britain. Plant Pathol. 38:93-97.

Gregory, S. C., Rishbeth, J., and Shaw, C. G., III. 1991. Pathogenicity and virulence. Pages 76-87 in: Armillaria root disease. Agricultural Handbook No. 691. C. G. Shaw III and G. A. Kile, eds. USDA Forest Service. Washington, D.C.

Gregory, S. C., and Watling, R. 1985. Occurrence of Armillaria borealis in Britain. Trans. Br. Mycol. Soc. 84:47-55.

Guillaumin, J. J., Legrand, P., Lung-Escarmant, B., and Botton, B. 2005. L'armillaire et le pourridié-agaric des végétaux ligneux. INRA, Paris.

Guillaumin, J. J., Mohammed, C., Anselmi, N., Courtecuisse, R., Gregory, S. C., Holdenrieder, O., Intini, M., Lung, B., Marxmuller, H., Morrison, D. J., Rishbeth, J., Termorshuizen, A. J., Tirro, A., and Vandam, B. 1993. Geographical-distribution and ecology of the Armillaria species in WesternEurope. Eur. J. Forest Pathol. 23:321-341.

Guillaumin, J. J., Mohammed, C., and Berthelay, S. 1989. Armillaria species in the northern temperate hemisphere. Pages 27-43 in: Proceedings of the 7th International Conference on Root and Butt Rots. Victoria and Vernon, British Columbia, Canada, 9-16 August 1988. D. J. Morrison, ed. Forestry Canada, Victoria, Canada.

Harrington, T. C., Worrall, J. J., and Baker, F. A. 1992. Armillaria. Pages 81-85 in: Methods for research on soilborne phytopathogenic fungi. L. L. Singleton, J. D. Mihail, and C. M. Rush, eds. APS Press, St. Paul, MN.

Heinzelmann, R., and Rigling, D. 2016. Mycelial fan formation of three sympatric Armillaria species on excised stem segments of Picea abies. Forest Pathol. 46: 187-199.

Keca, N., and Solheim, H. 2011. Ecology and distribution of Armillaria species in Norway. For. Pathol. 41:120-132.

Kim, M. S., Klopfenstein, N. B., Hanna, J. W., and McDonald, G. I. 2006. Characterization of North American Armillaria species: Genetic relationships determined by ribosomal DNA sequences and AFLP markers. For. Pathol. 36:145-164.

Korhonen, K. 1978. Interfertility and clonal size in the Armillariella mellea complex. Karstenia 18:31-42.

Laflamme, G., and Guillaumin, J. J. 2005. L'armillaire, agent pathogène mondial: Répartition et dégâts. Pages 273-289 in: L' armillaire et la pourridié-agaric des végétaux ligneux. J. J. Guillaumin, P. Legrand, B. Lung-Escarmant, and B. Botton, eds. INRA, Paris.

Legrand, P., Ghahari, S., and Guillaumin, J.-J. 1996. Occurrence of genets of Armillaria spp. in four mountain forests in Central France: The colonization strategy of Armillaria ostoyae. New Phytol. 133:321-332.

Lung-Escarmant, B., and Guyon, D. 2004. Temporal and spatial dynamics of primary and secondary infection by Armillaria ostoyae in a Pinus pinaster plantation. Phytopathology 94:125-131.

Maloy, O. C. 1974. Benomyl-malt agar for purification of cultures of wood decay fungi. Plant Dis. Rep. 58:902-904.

Marxmüller, H., and Guillaumin, J. J. 2005. Description et distribution des armillaires européennes. Pages 63-84 in: L'armillaire et le pourridié-agaric des végétaux ligneux. J. J. Guillaumin, P. Legrand, B. Lung-Escarmant, and B. Botton, eds. INRA, Paris.

Marxmüller, H., and Holdenrieder, O. 2000. Morphologie und Populationsstruktur der beringten Arten von Armillaria s.1. Mycologia Bavarica 4:9-32.

Marxmüller, H., Holdenrieder, O., and Müller, E. D. 1990. Zur Verbreitung, Phänologie und Ökologie von Armillaria mellea s.l. in Südbayern. Ber. Bayerischen Bot. Ges. 61:115-134.

Mohammed, C. 1985. Croissance et ramification du rhizomorphs des 5 espèces européennes d'armillaires du groupe "mellea". Agronomie 5:560.

Morrison, D. J. 2004. Rhizomorph growth habit, saprophytic ability and virulence of 15 Armillaria species. For. Pathol. 34:15-26.

Morrison, D. J., and Pellow, K. W. 2002. Variation in virulence among isolates of Armillaria ostoyae. For. Pathol. 32:99-107.

Omdal, D. W., Shaw, C. G., III, Jacoby, W. R., and Wager, T. C. 1995. Variation in pathogenicity and virulence of isolates of Armillaria ostoyae on eight tree species. Plant Dis. 79:939-944.

Pavlov, I. N. 2015. Biotic and abiotic factors as causes of coniferous forests dieback in Siberia and Far East. Contemp. Probl. Ecol. 8:440-456.

Prospero, S., Holdenrieder, O., and Rigling, D. 2003. Primary resource capture in two sympatric Armillaria species in managed Norway spruce forests. Mycol. Res. 107:329-338.

Prospero, S., Holdenrieder, O., and Rigling, D. 2004. Comparison of the virulence of Armillaria cepistipes and Armillaria ostoyae on four Norway spruce provenances. For. Pathol. 34:1-14.

Prospero, S., Holdenrieder, O., and Rigling, D. 2006. Rhizomorph production and stump colonization by co-occurring Armillaria cepistipes and Armillaria ostoyae: An experimental study. For. Pathol. 36:21-31.

Qin, G. F., Zhao, J., and Korhonen, K. 2007. A study on intersterility groups of Armillaria in China. Mycologia 99:430-441.

R Development Core Team. 2016. R: A language and environment for statistical computing. R Foundation for Statistical Computing, Vienna, Austria.

Rigling, D., Blauenstein, H., Walthert, L., Rigling, A., Kull, P., Schwyzer, A., and Heiniger, U. 1998. Rhizomorph producing Armillaria species in Norway spruce stands in Switzerland. Pages 259-265 in: Root and Butt Rots of Forest Trees. 9th International Conference on Root and Butt Rots. C. Delatour, B. Marcais, J. J. Guillaumin, and B. Lung-Escarmant, eds. INRA, Paris.

Rishbeth, J. 1985. Infection cycle of Armillaria and host response. Eur. J. Forest Pathol. 15:332-341.

Robinson, R. M., and Morrison, D. J. 2001. Lesion formation and host response to infection by Armillaria ostoyae in the roots of western larch and Douglas-fir. For. Pathol. 31:371-385.

Ross-Davis, A. L., Hanna, J. W., Kim, M. S., and Klopfenstein, N. B. 2012. Advances toward DNA-based identification and phylogeny of North American Armillaria species using elongation factor-1 alpha gene. Mycoscience 53: 161-165.

Shaw, C. G., III, and Roth, L. F. 1976. Persistence and distribution of a clone of Armillaria mellea in a Ponderosa pine forest. Phytopathology 66:1210-1213.

Siepmann, R. 1985. Über das Vorkommen von Armillaria-Arten und -Klonen in benachbarten Koniferenbeständen, Mischbeständen und in Laubwald. Eur. J. Forest Pathol. 15:71-80.

Siepmann, R., and Leibiger, M. 1989. Über die Wirtsspezialisierung von Armillaria-Arten. Eur. J. Forest Pathol. 19:334-342.

Tsykun, T., Rigling, D., and Prospero, S. 2013. A new multilocus approach for a reliable DNA-based identification of Armillaria species. Mycologia 105: 1059-1076.

Wargo, P. M., and Harrington, T. C. 1991. Host stress and susceptibility. Pages 88-101 in: Armillaria root disease. Agricultural Handbook No. 691. C. G. Shaw III and G. A. Kile, eds. USDA Forest Service, Washington, D.C. 